\title{
Blechnum patersonii subsp. queenslandicum, a new subspecies
}

\author{
T.C. Chambers and P.A. Farrant
}

\begin{abstract}
T.C. Chambers and P.A. Farrant (Royal Botanic Gardens, Sydney, NSW Australia 2000) 1995. Blechnum patersonii subsp. queenslandicum, a new subspecies. Telopea 6(2-3): 177-180. A new subspecies of Blechnum patersonii ( $R . B r$.) Mett., B. patersonii subsp. queenslandicum, is described, with notes on its distribution and habitat.
\end{abstract}

Blechnum patersonii subsp. queenslandicum Chambers \& Farrant, subsp. nov.

Blechno patersonii subspecie patersonii similis sed frondibus sterilibus crassioribus succulentioribus fragilioribusque (magis facile detectis in statu vivo), marginibus tenuioribus plerumque reflexis (in speciminibus exsiccatis) integribus vel subtiliter serratis differt.

Type: Queensland: $11.1 \mathrm{~km}$ (6.9 miles) by road WNW of Mt Lewis forestry hut (c. 13 km NW of Julatten P.O.), R. Coveny 7216 \& P. Hind, 20 Sept 1975; holo NSW 265764; iso BRI, DRA, Z.I

[Blechnum patersonii auct. non (R. Br.) Mett., referring to north Queensland specimens: Andrews, Ferns of Queensland: 93 (1990), in part.]

Blechnum patersonii var. elongatum Domin, Biblioth. Bot. 85: 109 (1915), in part. 'Montes Bellenden Ker' [Mount Bellenden Ker], K. Domin Iter Australiense 241, 1910; lecto (here chosen): PR 523487.

Rhizome short-creeping or erect, up to $2 \mathrm{~cm}$ in diameter, densely clothed with bases of old stipes; apex densely scaly; scales ovate, acuminate, $4-10 \mathrm{~mm} \times 1-3 \mathrm{~mm}$, concolorous dark reddish brown or bicolorous with paler margins, shiny, entire. Fronds dimorphic, erect, $7-80 \mathrm{~cm}$ long, $1-23 \mathrm{~cm}$ wide. Sterile fronds simple or pinnatisect; fertile fronds simple, pinnatisect or pinnate; to 7 pairs of pinnae (lobes). Stipes 2-13 cm below decurrent wings of lamina (similar for sterile and fertile fronds), stramineous, brown or reddish brown, darkest at the base; scales only at base of stipe, lanceolate or ovate, reddish brown, entire. Lamina narrow-lanceolate (simple fronds), lanceolate or ovate (pinnatisect or pinnate fronds). Rhachis and costae reddish brown, brown or stramineous (costae), with darker pigmentation on the undersurface and on more robust specimens, glabrous. Sterile pinnae (lobes) lanceolate, attenuate to aristate at apices, adnate and winged decurrently along rhachis, firm, fleshy and brittle when fresh, usually coriaceous when dry; margins thin, either minutely serrate (associated with glands and vein endings) or entire, teeth usually obscured by finely reflexed margins; middle lobes $2-13 \mathrm{~cm}$ long, $0.7-3.2 \mathrm{~cm}$ wide; terminal lobe longer than the subterminal few pairs; decurrent wings of lamina tissue extending well down below basal lobes and tapering into stipe (the decurrent wings often comprising half the total frond length); veins immersed, paler than the leaf tissue in dried specimens and more visible on the undersurface, close together and parallel, sometimes once-furcate. Fertile pinnae linear, aristate at apices, adnate to rhachis and winged decurrently, pinnae distant and fairly evenly spaced on rhachis; middle pinnae to $25 \mathrm{~cm}$ long, $5 \mathrm{~mm}$ wide; terminal pinna usually longer than subterminal few pairs; sori covering underside of lamina (of simple fronds), pinnae and wings 
(of pinnatisect or pinnate fronds) except at aristate apices; indusium brown, laciniate to more or less entire; spores $40 \times 29$ um (average of 17 spores viewed with scanning electron microscope), perine smooth to scabrate, granulate or microrugulate, exine smooth to microverrucate.

Distribution and habitat: Blechnum patersonii subsp. queenslandicum occurs in Queensland and north-eastern New South Wales, with the most distinct and robust forms being found in north Queensland. Both subsp. queenslandicum and subsp. patersonii occur in south-eastern Queensland, in the same habitats; both are terrestrial or lithophytic and found growing on moist banks near creeks, in wet sclerophyll forest and in rainforest.

Selected specimens: Queensland: Mt Roberts, Lamington National Park, S.T. Blake 21349, Aug 1960 (BRI, NSW); Eumundi, s.coll., May 1892 (BRI); Tinaroo Range, road from Downfall Creek, L.J. Webb \& J.G. Tracey 5783, Feb 1962 (BRI); Mt Lewis Road, L.S. Smith 10098, Aug 1957 (BRI); Mt Lewis, S.B. Andrezus 251 \& G. Stocker, May 1975 (BRI); Mt Bellenden Ker, valley to SW of Tower 3 (Cable Car), R.J. Chinnock 8352, June 1991 (AD, BRI, NSW); Eungella N.P., SE slopes of Mt William, $20.8 \mathrm{~km}$ by road N of Eungella township, P.D. Bostock 1145, Apr 1991 (NSW).

New South Wales: Dorrigo, I.G. Stone, Apr 1966 (NSW).

Notes: Blechnum patersonii subsp. queenslandicum has until now been included with B. patersonii sens. lat. in all herbaria. However, a number of the collections have annotations from the original field collectors who realised that this very striking fern was possibly distinct from the more frequently collected B. patersonii subsp. patersonii. Although the subspecies queenslandicum is easily recognised in the field because its fronds are quite fleshy, almost succulent, this feature is usually difficult to recognise in pressed specimens; in pressed specimens the lamina has thin marginal tissue so that the very finely serrate margins usually curl towards the undersurface and appear entire.

Blechnum patersonii subsp. patersonii is less robust, most plants being simple-fronded; pinnatisect/pinnate plants are not usually as large as plants of subsp. queenslandicum, although the degree of winging is similar for both subspecies. B. patersonii subsp. patersonii has a papery rather than succulent lamina that is more flexible and less brittle. The margins of the lamina are not usually revolute, they have larger and more obvious serrations that can be easily felt by running a finger along the margins, and the margins are also often crenate.

While only Blechnum patersonii subsp. queenslandicum occurs in north Queensland, both subspecies are found in south-eastern Queensland and north-eastern New South Wales. Specimens of B. patersonii subsp. queenslandicum from north Queensland are easily recognised both in the field and when pressed, by the above characters. The southernmost specimens of subsp. queenslandicum (e.g. from Eumundi, Lamington National Park and the New England area) have mostly revolute, entire margins, whereas the northernmost specimens of subsp. patersonii (e.g. from Carnarvon, Condamine and the New South Wales-Queensland border area) have distinctly serrate margins. Although dried herbarium specimens from south-eastern Queensland and north-eastern New South Wales are less distinct and may be difficult to separate without field notes about their texture, some herbarium specimens from the area of overlap clearly belong to the new subspecies and some fresh material collected in the New England area of New South Wales has been examined.

Although simple-fronded forms of Blechnum patersonii subsp. queenslandicum do occur, plants are usually more robust with more dissected laminas and stouter, more pigmented stipes than $B$. patersonii subsp. patersonii. These features are also characteristic of the New Zealand species Blechnum colensoi. However, in B. colensoi 


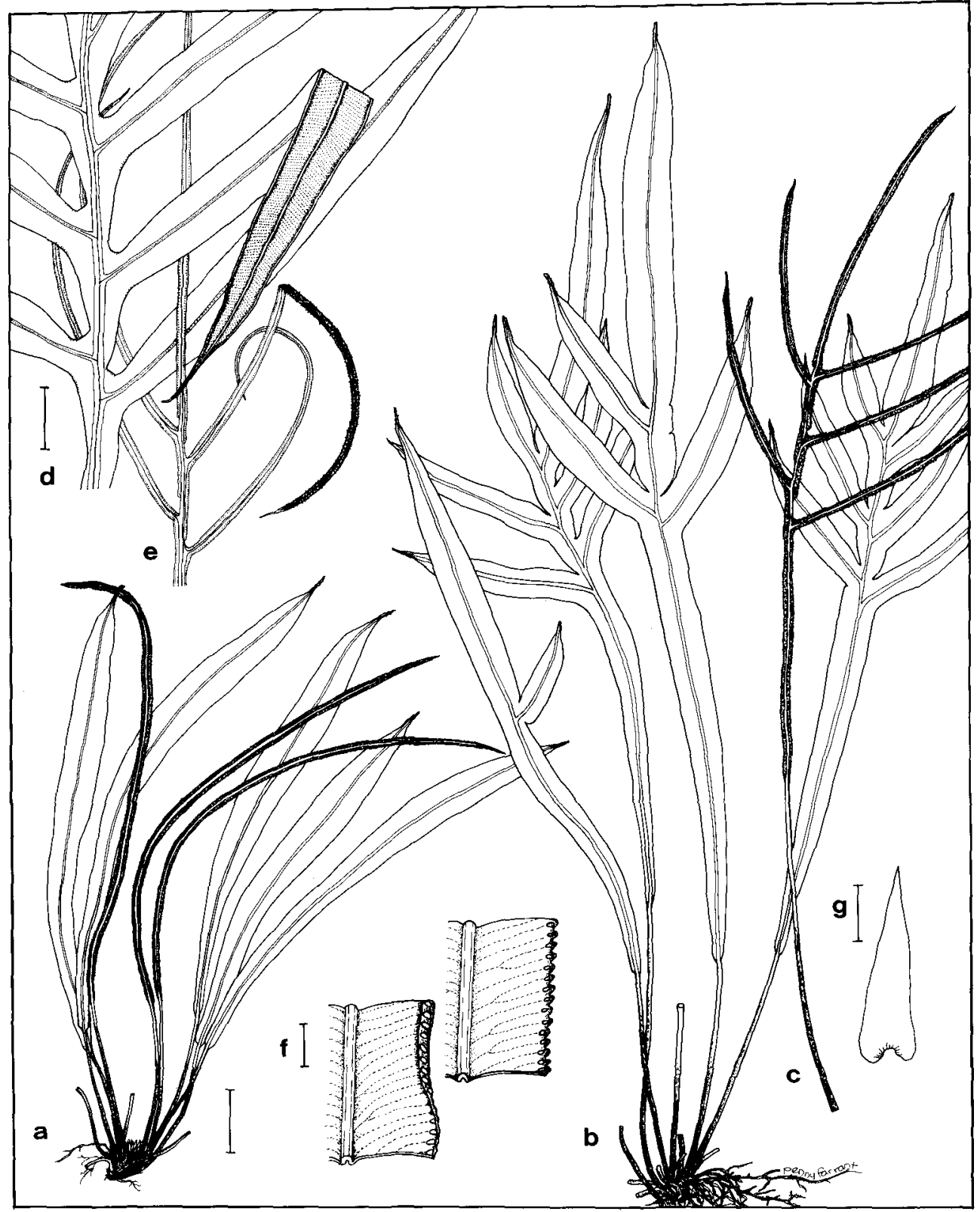

Fig. 1. Blechnum patersonii subsp. queenslandicum, a habit, simple-fronded form, bar $=3 \mathrm{~cm}$ [s.coll., Mar 1892, BRI]; b habit, pinnatisect form, sterile plant, same scale as a [R. Coveny 7216 E P. Hind, NSW]; c habit, pinnatisect form, fertile frond, same scale as a [L.S. Smith 10098, BRI]; d detail of abaxial surface of sterile pinna, bar $=2 \mathrm{~cm}$ [R.J. Chinnock 8352, NSW]; e detail of abaxial surface of fertile pinna, same scale as $\mathbf{d}$ [P.D. Bostock 1145, NSW]; $\mathbf{f}$ detail of veins and margin in part of sterile pinna (abaxial surface), subsp. queenslandicum (left) [R.]. Chinnock 8352, NSW] and subsp. patersonii (right) [J.D. Lovis 219, NSW 265684], bar $=5 \mathrm{~mm}$; g scale from apex of rhizome of sterile frond, bar $=2 \mathrm{~mm}[R$. Coveny $7216 \&$ \& . Hind, BRI]. 
not only is the lamina much thicker but the lobes are much broader and the base of the lamina is auriculate rather than winged; in B. patersonii subsp. queenslandicum the base of the lamina is winged, although on a few specimens from north Queensland the wings break up at the very base into one or two auricle-like segments.

Although Blechnum patersonii subsp. queenslandicum appears to be endemic to eastern Australia, careful study of specimens with succulent brittle foliage, apparently entire margins, and continuous wings of leaf material tapering into stipe, indicates that these characters are typical of a species-complex extending from eastern Australia into Malesia and requiring further investigation. In Timor the plants have apparently entire margins and, judging from dried specimens, probably thicker, more fleshy, coriaceous fronds.

\section{Acknowledgements}

We wish to thank Dr Peter Wilson (NSW) for help with the Latin diagnoses, Mr Peter Bostock (BRI) for helpful comments on the manuscript, and BRI herbarium for loan of specimens. 